\title{
PENENTUAN MODEL INDEKS HARGA SAHAM GABUNGAN (IHSG) MENGGUNAKAN ANALISIS FUNGSI TRANSFER
}

\author{
Luh Juni Asrini \\ Jurusan Teknik Industri, Universitas Katolik Widya Mandala Surabaya \\ Email: juniasrini@ukwms.ac.id
}

\begin{abstract}
ABSTRAK
Permasalahan yang seringkali dihadapi oleh investor dalam dunia industri pasar modal, berkaitan dengan pengambilan keputusan mengenai penanaman suatu investasi pada penyertaan saham adalah ketidakpastian faktorfaktor internal, eksternal dan global. Salah satu indikator nasional yang dijadikan pegangan oleh para investor adalah Indeks Harga Saham Gabungan (IHSG). Oleh karena itu dalam penelitian ini akan dilakukan suatu pemodelan dari IHSG dengan menggunakan analisis fungsi transfer. Faktor-faktor yang berpengaruh terhadap IHSG adalah harga emas dunia (Harga emas dunia), indeks harga saham Nikkei, indeks harga saham Hangseng, Dow Jones Industrial Average (indeks DJI), dan nilai tukar Rupiah terhadap dollar Amerika (kurs). Tujuan dari penelitian ini adalah untuk mendapatkan metode peramalan yang tepat melalui metode fungsi transfer yang dapat digunakan memprediksi nilai IHSG, sehingga dapat membantu para investor dalam mengambil keputusan terhadap dana yang akan diinvestasikan. Selain itu, untuk mengetahui hubungan antara Harga emas dunia, indeks Nikkei, indeks Hangseng, indeks DJI, dan kurs terhadap IHSG melalui metode fungsi transfer. Hasilnya menunjukkan bahwa model fungsi transfer dengan input kurs merupakan model terbaik yang dapat digunakan untuk meramalkan IHSG periode ke depan. Hasilnya juga menunjukkan bahwa prediktor yang signifikan adalah Harga emas dunia, indeks Nikkei, indeks Hangseng, indeks DJI, dan kurs.
\end{abstract}

Kata kunci: model fungsi transfer, IHSG

\section{PENDAHULUAN}

Permasalahan yang seringkali dihadapi oleh investor dalam dunia industri pasar modal, berkaitan dengan pengambilan keputusan mengenai suatu investasi pada penyertaan saham adalah ketidakpastian faktor-faktor internal, eksternal dan global. Suatu indikator keberhasilan dunia investasi di Indonesia adalah Indeks Harga Saham Gabungan (IHSG) (Anoraga,2003). IHSG adalah indeks rata-rata gabungan seluruh saham yang diperjualbelikan di Bursa Efek Indonesia (BEI). Penelitian ini membuat model peramalan untuk IHSG dengan menggunakan model ekonometrika yang melibatkan variabel prediktor yaitu fungsi transfer. Model fungsi transfer merupakan fungsi dinamis, yang pengaruhnya tidak hanya pada hubungan linier antara waktu ke-t input dan waktu ke-t output, tetapi berpengaruh juga terhadap hubungan saat $t, t+1, t+2, \ldots$, $\mathrm{t}+\mathrm{k}$ pada output (Wei, 1990). Dalam bidang perekonomian, fungsi transfer telah banyak diaplikasikan. Deret output pada penelitian ini adalah IHSG dan deret inputnya adalah indeks Dow Jones, indeks Nikkei, indeks Hangseng, nilai kurs rupiah terhadap dollar Amerika dan harga emas dunia. Dengan pemodelan IHSG ini diharapkan mampu memprediksi arah dari IHSG untuk menentukan kebijakan dalam dunia investasi di Indonesia.

Berdasarkan uraian di atas pada penelitian ini dibahas tentang model peramalan IHSG dengan memperhatikan indeks Dow Jones Industrial Average (DJI), indeks harga saham Nikkei, indeks harga saham Hangseng (HIS), nilai tukar Rupiah terhadap dolar Amerika (kurs), dan harga emas dunia menggunakan metode fungsi transfer. Di samping itu juga dibahas tentang performansi masing-masing model dengan deret input indeks Dow Jones Industrial Average (DJI), indeks harga saham Nikkei, indeks harga saham Hangseng (HIS), nilai tukar Rupiah terhadap dolar Amerika (kurs), dan harga emas dunia, serta model multi input untuk meramalkan IHSG 12 bulan ke depan dengan memanfaatkan model yang telah diperoleh. 


\section{MATERI DAN METODE}

\section{Model ARIMA Box - Jenkin's}

Model ARIMA Box-Jenkins terdiri dari dua jenis model, yaitu model data deret waktu yang stasioner dan model data deret waktu yang nonstasioner. Termasuk model data yang stasioner adalah model Autoregressive orde $p$ atau AR(p), model Moving Average orde $q$ atau $M A(q)$ dan model campuran antara Autoregressive dengan Moving Average yang disebut dengan ARMA $(p, q)$. Sedangkan model data yang nonstasioner dapat berupa model Autoregressive Integrated Moving Average atau $\operatorname{ARIMA}(p, d, q)$ untuk nonmusiman dan $\operatorname{ARIMA}(P, D, Q)^{s}$ untuk musiman (Makridakis,1983).

1. Model Autoregressive orde $\mathrm{p}$ atau $A R(p)$

Model AR ditulis $\phi_{p}(B) Z_{t}=a_{t}$ yang merupakan fungsi dari :

$$
\begin{aligned}
& Z_{t}=\phi_{1} Z_{t-1}+\ldots+\phi_{p} Z_{t-p}+a_{t} \\
& \text { dengan } \phi_{p}(B)=\left(1-\phi_{1} B-\ldots-\phi_{p} B^{p}\right)
\end{aligned}
$$

2. Model Moving Average orde q atau $M A(q)$

Model MA ditulis $Z_{t}=\theta_{q}(B) a_{t}$ yang merupakan fungsi dari :

$$
Z_{t}=a_{t}-\theta_{1} a_{t-1}-\ldots-\theta_{q} a_{t-q}
$$

$$
\text { dengan } \theta_{q}(B)=\left(1-\theta_{1} B-\ldots-\theta_{q} B^{q}\right)
$$

3. Model Autoregressive Moving Average atau ARMA $(p, q)$

Model $\operatorname{ARMA}(p, q)$ adalah suatu model campuran antara Autoregressive orde $p$ dengan model Moving Average orde $q$. Bentuk umum model ini adalah :

$$
\phi_{p}(B) Z_{t}=\theta_{q}(B) a_{t}
$$

$$
\text { dengan }
$$

$$
\begin{aligned}
& \phi_{p}(B)=1-\phi_{1} B-\ldots-\phi_{p} B^{p} \text { dan } \\
& \theta_{p}(B)=1-\theta_{1} B-\ldots-\theta_{q} B^{q}
\end{aligned}
$$

4. Model autoregressive integrated moving average atau $\operatorname{ARIMA}(p, d, q)$

Model $\operatorname{ARIMA}(p, d, q)$ ini merupakan model deret waktu yang nonstasioner. $\operatorname{ARIMA}(p, d, q)$ merupakan gabungan antara model AR dan model MA dengan differencing berorde $\mathrm{d}$. Bentuk umum dari model ini adalah:

$\phi_{p}(B)(1-B)^{d} Z_{t}=\theta_{0}+\theta_{q}(B) a_{t}$

dengan $\phi_{p}(B)=\left(1-\phi_{1} B-\ldots-\phi_{p} B^{p}\right)$ merupakan operator AR yang stasioner dan $\theta_{q}(B)=\left(1-\theta_{1} B-\ldots-\theta_{q} B^{q}\right)$ adalah operator MA yang invertible.

\section{Konsep Fungsi Transfer}

Metode fungsi transfer merupakan suatu metode yang digunakan untuk meramalkan nilai dari suatu deret waktu (deret output $y_{t}$ ) yang didasarkan pada nilai-nilai masa lalu dari deret itu sendiri dan juga didasarkan pula pada satu atau lebih deret waktu yang berhubungan dengan deret output tersebut (deret input $x_{t}$ ). Bentuk umum model fungsi transfer single input $x_{t}$ dan single output $y_{t}$ adalah (Wei, 1990) :

$$
y_{t}=v(B) x_{t}+\eta_{t}
$$


dengan :

$y_{t}=$ deret output yang stationer

$x_{t}=$ deret input yang stationer

$n_{t}=$ deret noise

dengan $v(B)=\frac{\omega_{s}(B) B^{b}}{\delta_{r}(B)}$

sehingga $\quad y_{t}=\frac{\omega_{s}(B) B^{b}}{\delta_{r}(B)} x_{t}+\eta_{t}$

atau $\quad y_{t}=\frac{\omega_{s}(B) B^{b}}{\delta_{r}(B)} x_{t}+\frac{\theta(B)}{\phi(B)} a_{t}$

dengan $\omega_{s}(B)=\omega_{0}-\omega_{1} B-\omega_{2} B^{2}-\ldots-\omega_{s} B^{s}$

$$
\begin{gathered}
\delta_{r}(B)=1-\delta_{1} B-\delta_{2} B^{2} \ldots-\delta_{r} B^{r} \\
\theta(B)=1-\theta_{1} B-\theta_{2} B^{2}-\ldots-\theta_{q} B^{q} \\
\phi(B)=1-\phi_{1} B-\phi_{2} B^{2}-\ldots-\phi_{p} B^{p}
\end{gathered}
$$

Pada fungsi transfer multi input ada beberapa $x$ variabel input yang dimasukkan pada suatu pemodelan, sehingga bentuk persamaannya dapat ditulis (Edlund, 1984):

$$
y_{t}=\sum_{j=1}^{m} \frac{\omega_{j}(B)}{\delta_{j}(B)} x_{j, t-b_{j}}+\frac{\theta(B)}{\phi(B)} a_{t}
$$

dengan :

$y_{t} \quad=$ deret output

$x_{j t} \quad=$ deret input ke-j, dengan $\mathrm{j}=1,2, \ldots, \mathrm{m}$

$\omega_{j}(B)=$ operator Moving Average order $\mathrm{s}_{\mathrm{j}}$ untuk deret ke-j

$\delta_{j}(B)=$ operator Autoregressive order $\mathrm{r}_{\mathrm{j}}$ untuk deret ke- $\mathrm{j}$

$\theta(B)=$ operator Moving Average order q

$\phi(B)=$ operator Autoregressive order $\mathrm{p}$

$$
a_{t} \quad=\text { berdistribusi } \mathrm{N}\left(0, \sigma_{a}^{2}\right) \text { (white noise) }
$$

\section{SUMBER DATA}

Data yang digunakan pada penelitian ini adalah data IHSG, data indeks Dow Jones, data indeks Nikkei225, data indeks Hangseng, data nilai tukar rupiah terhadap dollar Amerika dan data harga emas dunia. Data yang digunakan merupakan data sekunder yang diperoleh berasal dari yahoo finance yaitu pengamatan dari tahun 2003 sampai dengan tahun 2014. Variabel yang diteliti dalam penelitian ini terdiri atas variabel respon sebagai deret output dan variabel predictor sebagai deret input. Adapun yang menjadi deret output adalah IHSG $(Y)$ dan yang menjadi deret input adalah indeks Dow Jones $\left(X_{1}\right)$, indeks Nikkei225 $\left(X_{2}\right)$, indeks Hangseng $\left(X_{3}\right)$, nilai tukar rupiah terhadap dollar Amerika $\left(X_{4}\right)$, dan harga emas dunia $\left(X_{5}\right)$. 


\section{METODE PENELITIAN}

Secara garis besar penelitian ini dilakukan dalam empat tahap, yaitu pertama identifikasi bentuk model, kedua penaksiran parameter-parameter model fungsi transfer, ketiga pemerikasaan diagnostic model fungsi transfer, dan keempat penggunaan model fungsi transfer untuk peramalan IHSG. Langkah-langkah penelitian secara lengkap diberikan pada flowchart berikut:
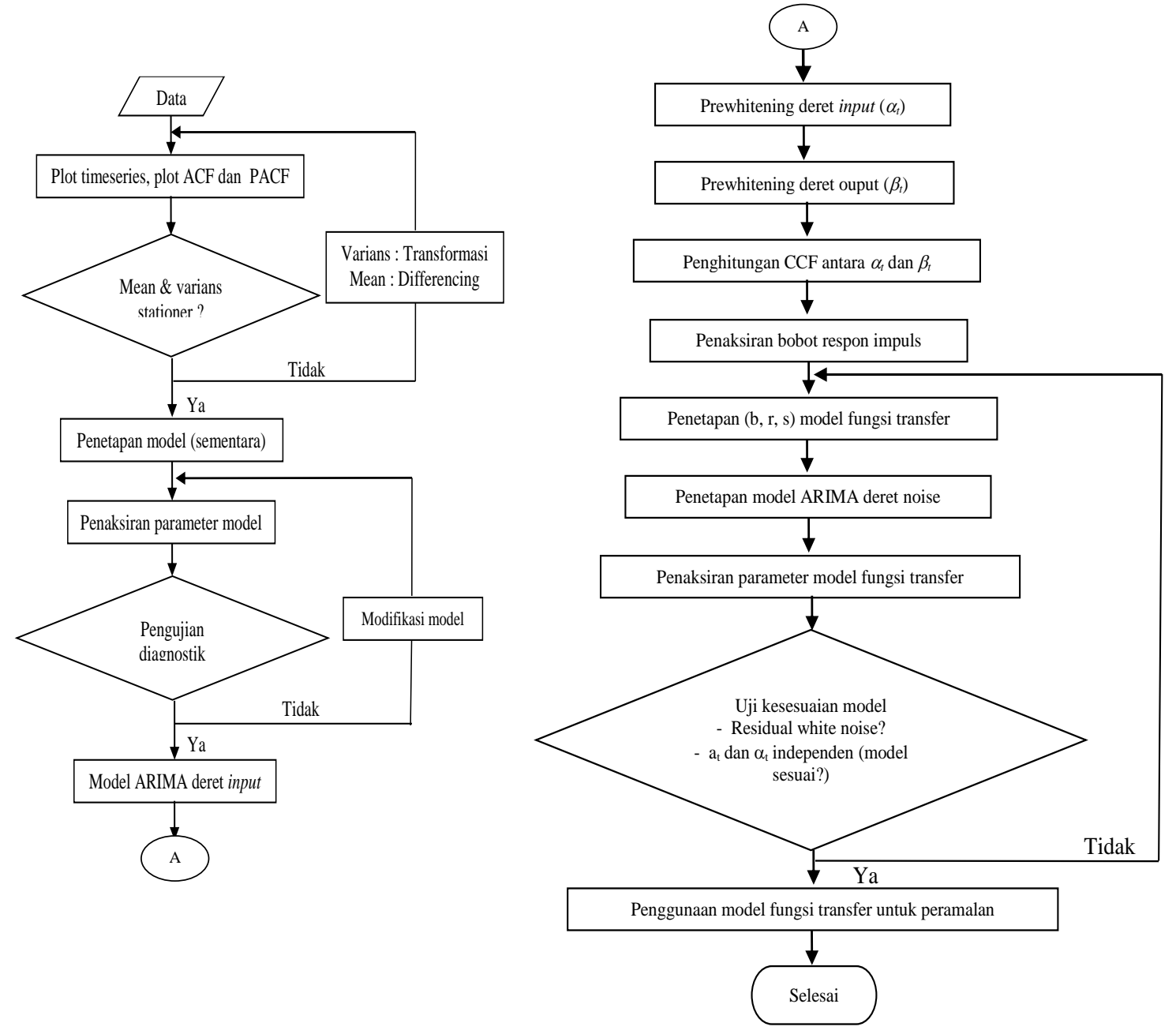

Gambar 1. Flowchart Penelitian

\section{HASIL DAN PEMBAHASAN}

Sebelum dilakukan pengolahan data, terlebih dahulu data dibagi menjadi dua bagian, yaitu sebagai data in sample dan data out sample. Data dari bulan Januari 2005 sampai dengan bulan Desember 2013 digunakan sebagai data in sample, yaitu data yang digunakan untuk membangun model. Sedangkan data dari bulan Januari 2014 sampai dengan Februari 2015 digunakan sebagai data out sample, yaitu data yang digunakan untuk validasi model.

\section{Pemodelan Fungsi Transfer IHSG dengan Deret Input Harga emas dunia $\left(x_{t}\right)$}

Pada bagian ini, analisis fungsi transfer digunakan untuk menggambarkan nilai IHSG yang berperan sebagai deret output ( $y_{t}$ ) dan deret harga emas dunia yang berperan sebagai deret input $\left(x_{1 t}\right)$. Tahapan yang dapat dilakukan adalah sebagai berikut. 


\section{Tahap Identifikasi Model Deret Input Harga Emas Dunia $\left(x_{1}\right)$}

Dalam memodelkan deret Harga emas dunia langkah awal yang harus dilakukan adalah dengan time series plot untuk melihat pola dari data tersebut. Berikut merupakan gambar time series plot untuk data harga emas dunia sebagai deret input $\left(x_{1}\right)$ dan data IHSG sebagai deret output $(y)$.

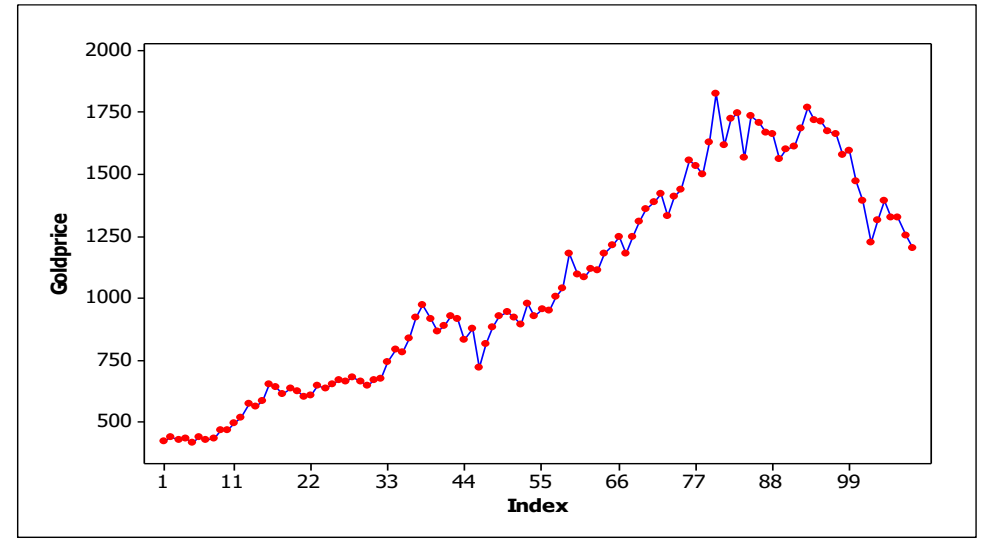

Gambar 2. Time series plot data harga emas dunia

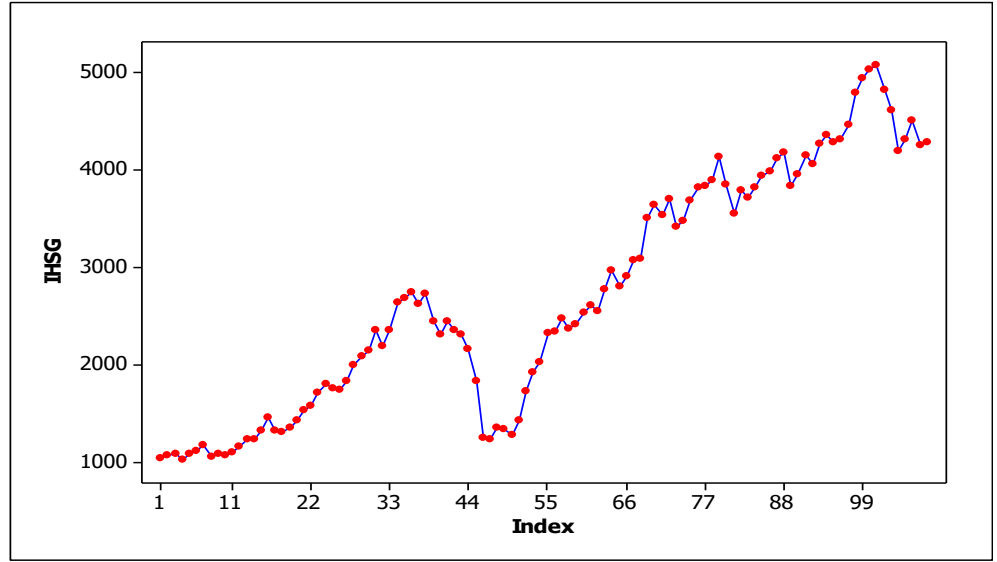

Gambar 3. Time series plot data IHSG

Berdasarkan Gambar 1 dan Gambar 2 terlihat bahwa data harga emas dunia dan IHSG tidak stationer dalam mean dan varian. Sehingga harus dilakukan transformasi ln untuk data harga emas dunia dan transformasi akar kuadrat untuk data IHSG, serta masing-masing dilakukan differencing 1. Plot data yang sudah stationer dalam mean dan varian dapat dilihat pada Gambar 3 dan Gambar 4.

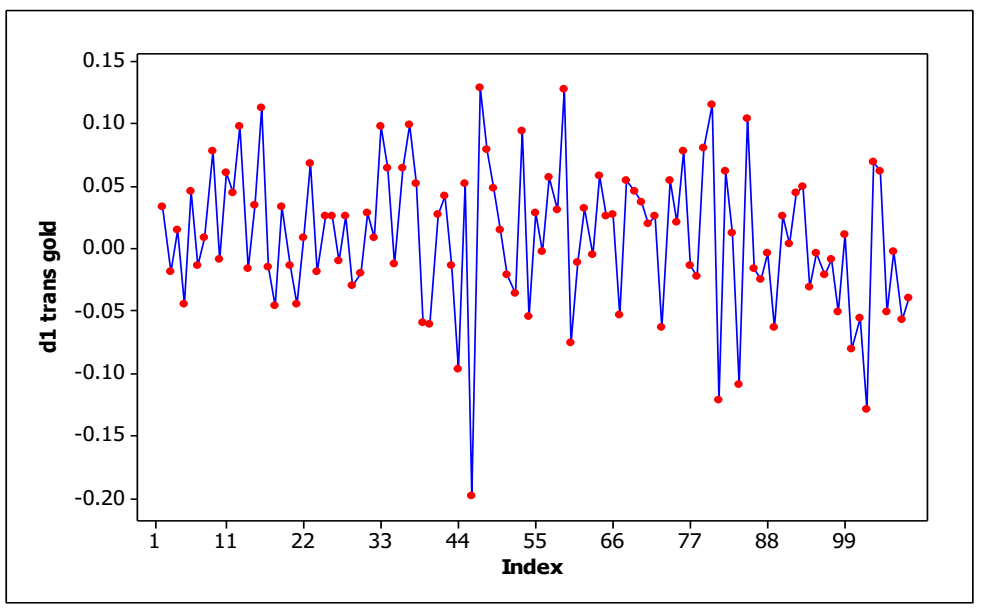

Gambar 4.Time Series Plot data Harga emas dunia setelah ditransformasi dan differencing 


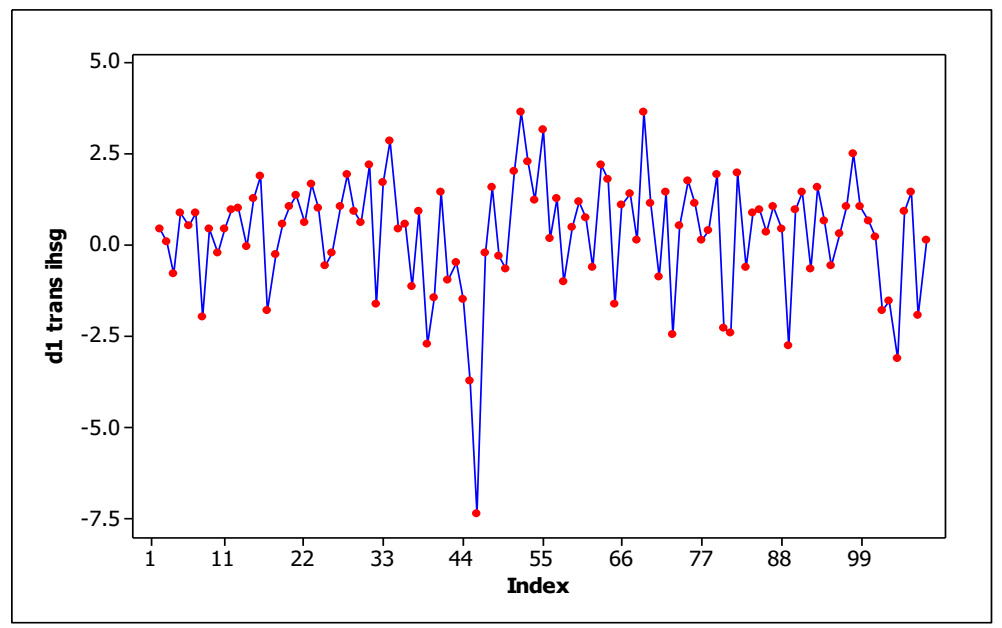

Gambar 5.Time Series Plot data IHSG setelah ditransformasi dan differencing

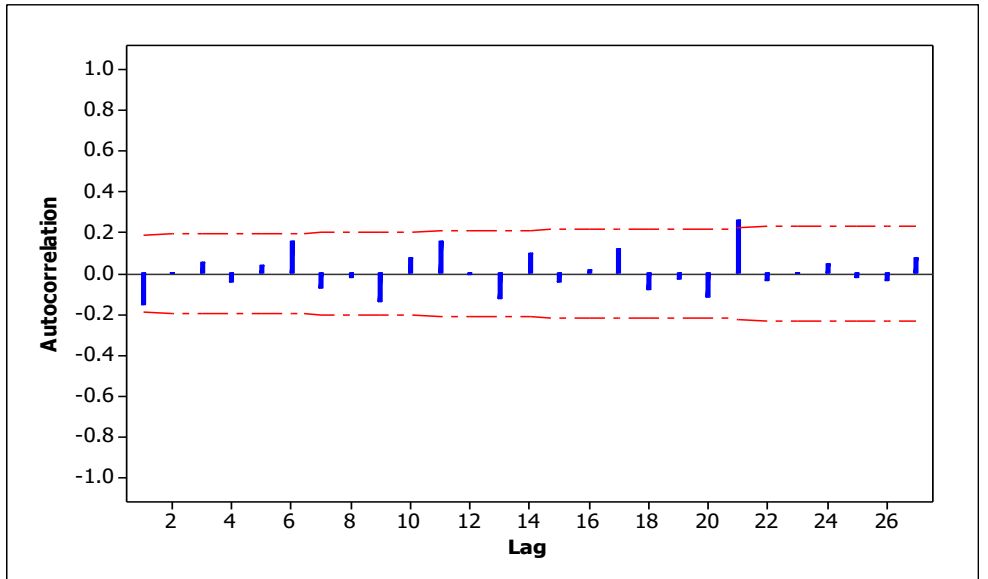

Gambar 6. Plot ACF data harga emas dunia setelah ditransformasi dan differencing

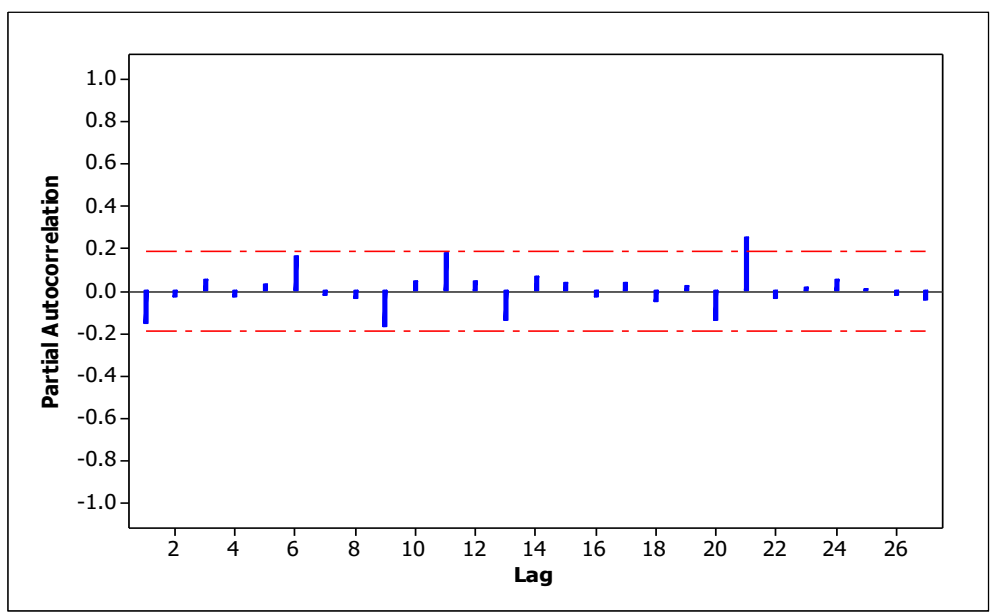

Gambar 7. Plot PACF data harga emas dunia setelah ditransformasi dan differencing

Berdasarkan identifikasi plot ACF dan PACF, model yang sesuai untuk data harga emas dunia adalah ARIMA([21],1,0). Model ini telah memiliki parameter yang signifikan dan p-value yang kurang dari 0,05 dan white noise. Model yang sesuai dengan ARIMA ([21],1,0) adalah sebagai berikut. 


$$
\left(1-0.31575 B^{21}\right)(1-B) Z_{t}=a_{1 t}
$$

\section{Prewhitening Deret Input Harga Emas Dunia $\left(x_{1}\right)$ dan Deret Output IHSG $\left(y_{t}\right)$}

Prewhitening dilakukan pada deret input dan deret output. Model deret input harga emas dunia $\left(x_{1}\right)$ adalah ARIMA $([21], 1,0)$ dan deret output $\left(y_{t}\right)$ IHSG juga mengikuti model ARIMA Harga emas dunia, maka prewhitening sebagai berikut.

dan

$$
\begin{aligned}
& a_{1 t}=\left(1-0.31575 B^{21}\right) x_{1 t} \\
& \beta_{1 t}=\left(1-0.31575 B^{21}\right) y_{t}
\end{aligned}
$$

\section{Pembentukan nilai $(b, r, s)$ pada model fungsi transfer}

Pada tahap ini dilakukan pemeriksaan nilai sampel Cross corelation (CCF) antara $\alpha_{1 \mathrm{t}}$ dan $\beta_{1 \mathrm{r}}$ untuk menduga $\mathrm{b}, \mathrm{r}$ dan s dari model fungsi transfer. Berikut gambar plot CCF antara deret Harga emas dunia dengan deret IHSG.

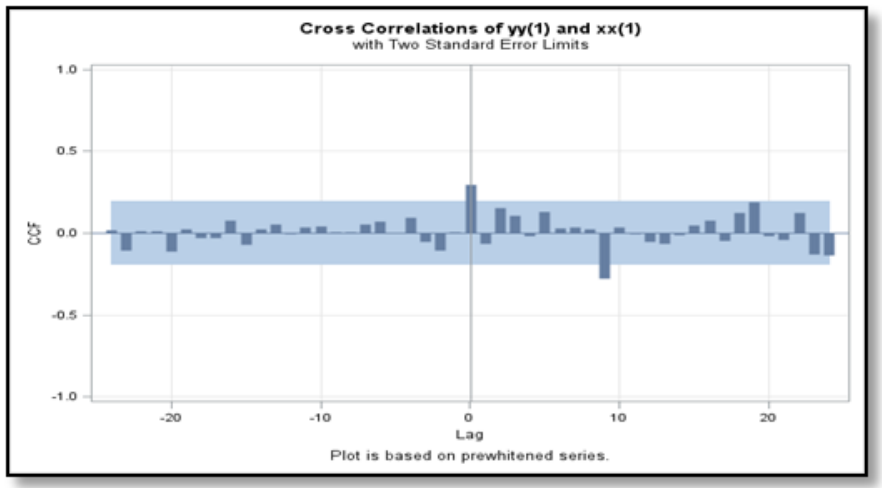

Gambar 8.Plot CCF deret harga emas dunia dengan deret IHSG

Dengan melihat plot CCF pada Gambar 7, dapat diketahui bahwa harga emas dunia berpengaruh signifikan terhadap IHSG pada lag ke-0, sehingga ditentukan nilai $b=0$. Karena plot CCF tidak menunjukkan pola yang jelas setelah lag ke-0, maka diduga $r=0$ dan $s=9$. Dugaan sementara untuk model fungsi transfer adalah:

$$
v(B) x_{t}=\left(\omega_{0}-\omega_{9} B^{9}\right) x_{1 t}
$$

\section{Identifikasi Model ARIMA untuk Deret Noise}

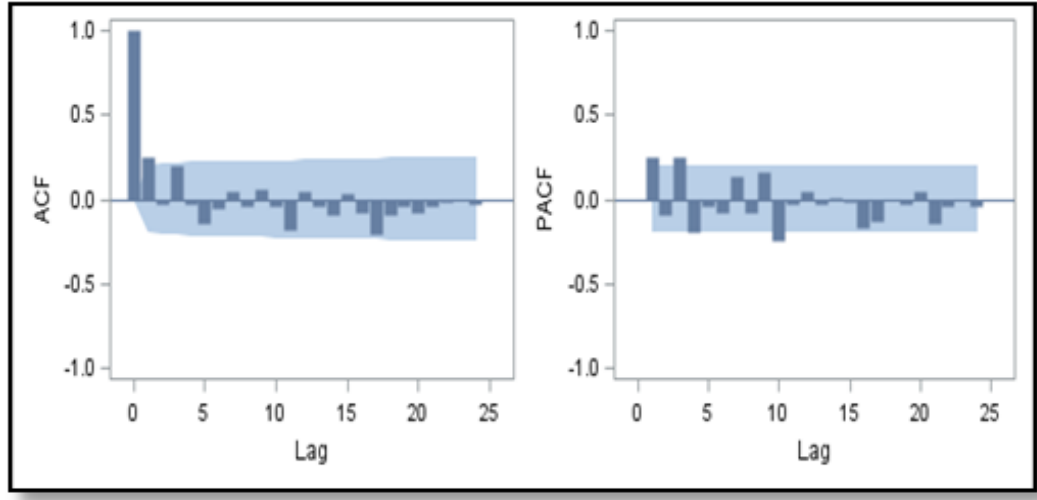

Gambar 9. Plot ACF dan PACF deret noise harga emas dunia 
Model yang sesuai untuk noise ini adalah ARIMA ([1, 3],1,0) karena semua parameternya telah signifikan dan memenuhi asumsi white noise. Setelah diperoleh model deret noise maka model fungsi transfer IHSG dengan deret input Harga emas dunia $\left(x_{1}\right)$ yang telah memenuhi white noise adalah sebagai berikut.

$$
\begin{aligned}
y_{t}= & \left(\omega_{0}-\omega_{9} B^{9}\right) x_{1 t}+\frac{1}{1-\phi_{1} B^{1}-\phi_{3} B^{3}} a_{1 t} \\
y_{t}= & y_{t-1}+0.2847\left(y_{t-1}-y_{t-2}\right)+0.2395\left(y_{t-3}-y_{t-4}\right)+7.914\left(x_{1 t}-x_{1 t-1}\right)-2.253\left(x_{1 t-1}-x_{1 t-2}\right)+ \\
& -1.896\left(x_{1 t-3}-x_{1 t-4}\right)-8.269\left(x_{1 t-9}-x_{1 t-10}\right)+2.354\left(x_{1 t-10}-x_{1 t-11}\right)+1.981\left(x_{1 t-12}-x_{1 t-13}\right)+a_{1 t}(16)
\end{aligned}
$$

\section{Pemodelan Fungsi Transfer dengan deret input indeks Nikkei, indeks Hangseng, indeks DJI, dan Kurs}

Pemodelan Fungsi Transfer untuk menggambarkan nilai IHSG yang berperan sebagai deret output dan deret indeks Nikkei, indeks Hangseng, indeks DJI, dan Kurs masing-masing sebagai deret input dilaukan hal yang sama seperti pada pemodelan fungsi transfer IHSG dengan deret Harga emas dunia sebagai deret input. Sehingga diperoleh empat model fungsi transfer sebagai berikut:

\section{Model Fungsi Transfer dengan Deret Input Indeks Nikkei}

Pada bagian ini, analisis fungsi transfer digunakan untuk menggambarkan nilai IHSG yang berperan sebagai deret output $\left(y_{t}\right)$ dan deret indeks Nikkei yang berperan sebagai deret input $\left(x_{2}\right)$. Model Fungsi transfer yang diperoleh adalah sebagai berikut.

$$
\begin{aligned}
y_{t}= & \left(\omega_{0}-\omega_{1} B^{1}\right) x_{2 t}+\frac{1}{1-\phi_{1} B^{1}-\phi_{3} B^{3}} a_{2 t} \\
y_{t}= & y_{t-1}+0.225\left(y_{t-1}-y_{t-2}\right)+0.235\left(y_{t-3}-y_{t-4}\right)+0.001\left(x_{2 t}-x_{2 t-1}\right)-0.0003\left(x_{2 t-1}-x_{2 t-2}\right)+ \\
& -0.0003\left(x_{2 t-3}-x_{2 t-4}\right)+0.0006\left(x_{2 t-1}-x_{2 t-2}\right)-0.00013\left(x_{2 t-2}-x_{2 t-3}\right)+ \\
& -0.00013\left(x_{2 t-4}-x_{2 t-5}\right)+a_{2 t}
\end{aligned}
$$

\section{Model Fungsi Transfer dengan Deret Input Indeks Hangseng}

Pada bagian ini, analisis fungsi transfer digunakan untuk menggambarkan nilai IHSG yang berperan sebagai deret output ( $y_{t}$ ) dan deret indeks Hangseng yang berperan sebagai deret input $\left(x_{3}\right)$. Model Fungsi transfer yang diperoleh adalah sebagai berikut.

$$
\begin{gathered}
y_{t}=\left(\omega_{0}-\omega_{1} B^{1}\right) x_{3 t}+a_{3 t} \\
y_{t}=y_{t-1}+15.94198\left(x_{3 t}-x_{3 t-1}\right)+3.93175\left(x_{3 t-1}-x_{3 t-2}\right)+a_{3 t}
\end{gathered}
$$

\section{Model Fungsi Transfer dengan Deret Input Indeks DJI}

Pada bagian ini, analisis fungsi transfer digunakan untuk menggambarkan nilai IHSG yang berperan sebagai deret output $\left(y_{t}\right)$ dan deret indeks DJI yang berperan sebagai deret input $\left(x_{4}\right)$. Model Fungsi transfer yang diperoleh adalah sebagai berikut.

$$
\begin{aligned}
& y_{t}=\left(\omega_{0}-\omega_{17} B^{17}\right) x_{4 t}+a_{4 t} \\
& y_{t}=y_{t-1}+0.0019\left(x_{4 t}-x_{4 t-1}\right)-0.00067\left(x_{4 t-17}-x_{4 t-18}\right)+a_{4 t}
\end{aligned}
$$




\section{Model Fungsi Transfer dengan Deret Input Kurs}

Pada bagian ini, analisis fungsi transfer digunakan untuk menggambarkan nilai IHSG yang berperan sebagai deret output $\left(y_{t}\right)$ dan deret Kurs yang berperan sebagai deret input $\left(x_{5}\right)$. Model Fungsi transfer yang diperoleh adalah sebagai berikut.

$$
\begin{aligned}
& y_{t}=\omega_{0} x_{5 t}+\frac{1}{1-\phi_{3} B^{3}} a_{5 t} \\
& y_{t}=y_{t-1}+0.23342\left(y_{t-3}-y_{t-4}\right)-0.0023786\left(x_{5 t}-x_{5 t-1}\right)+0.000555213\left(x_{5 t-3}-x_{5 t-4}\right)+a_{5 t}
\end{aligned}
$$

\section{Pemodelan IHSG dengan Fungsi Transfer Multi Input}

Pemodelan fungsi transfer multi input dilakukan setelah model fungsi transfer single input telah diperoleh untuk semua deret input. Model fungsi transfer multi input memasukkan semua deret input ke dalam model secara bersama-sama. Model yang diperoleh adalah:

$$
\begin{aligned}
y_{t}= & \omega 1_{0} x 1_{t}+\left(\omega 2_{0}-\omega 2_{2} B^{2}\right) x 2_{t}+\frac{\omega 3_{0}}{1-\delta 3_{1} B^{1}} x 3_{t}+\omega 4_{0} x 4_{t}+\omega 5_{0} x 5_{t}+\frac{1}{1-\phi_{2} B^{2}} a_{t} \\
y_{t}= & y_{t-1}+0.2614\left(y_{t-2}-y_{t-3}\right)-0.4690\left(y_{t-1}-y_{t-2}\right)-0.1226\left(y_{t-3}-y_{t-4}\right)+6.1891\left(x 1_{t}-x 1_{t-1}\right)+ \\
& 1.6178\left(x 1_{t-2}-x 1_{t-3}\right)-2.9027\left(x 1_{t-1}-x 1_{t-2}\right)-0.7588\left(x 1_{t-3}-x 1_{t-4}\right)+0.0005\left(x 2_{t}-x 2_{t-1}\right)+ \\
& 0.0001\left(x 2_{t-2}-x 2_{t-3}\right)-0.0002\left(x 2_{t-1}-x 2_{t-2}\right)-0.00005\left(x 2_{t-3}-x 2_{t-4}\right)-0.0004\left(x 2_{t-2}-x 2_{t-3}\right)+ \\
& -0.0001\left(x 2_{t-4}-x 2_{t-5}\right)+0.0002\left(x 2_{t-3}-x 2_{t-4}\right)+0.00005\left(x 2_{t-5}-x 2_{t-6}\right)+6.7579\left(x 3_{t}-x 3_{t-1}\right)+ \\
& 1.7665\left(x 3_{t-2}-x 3_{t-3}\right)+0.0008\left(x 4_{t}-x 4_{t-1}\right)+0.0002\left(x 4_{t-2}-x 4_{t-3}\right)-0.0004\left(x 4_{t-1}-x 4_{t-2}\right)+ \\
& -0.000099\left(x 4_{t-3}-x 4_{t-4}\right)-0.0011\left(x 5_{t}-x 5_{t-1}\right)-0.0003\left(x 5_{t-2}-x 5_{t-3}\right)+0.0005\left(x 5_{t-1}-x 5_{t-2}\right)+ \\
& 0.00014\left(x 5_{t-3}-x 5_{t-4}\right)+a_{t}
\end{aligned}
$$

Persamaan di atas berarti bahwa IHSG pada waktu ke-t dipengaruhi oleh IHSG itu sendiri saat t1, t-2, t-3, dan t-4. Selain itu, dipengaruhi oleh harga emas dunia pada waktu ke- t, t-1, t-2, t-3 dan $\mathrm{t}-4$, oleh indeks Nikkei pada waktu ke-t, t-1, t-2, t-3, t-4, t-5, dan t-6, oleh indeks Hangseng pada waktu ke-t, t-1, t-2 dan t-3, oleh indeks DJI pada waktu ke- t, t-1, t-2, t-3, dan t-4, serta Kurs pada waktu ke- t, t-1, t-2, t-3, dan t-4, dan nilai error pada waktu ke-t

\section{Forecasting untuk 12 periode ke depan}

Hasil ramalan yang diperoleh untuk keempat model fungsi transfer dilakukan dengan 2 cara, yaitu secara serentak dan one step forecating a head. Time Series Plot perbandingan antara data aktual IHSG dengan hasil peramalan untuk keenam model secara serentak dapat dilihat pada Gambar 9 dan secara one step forecating a head pada gambar 10.

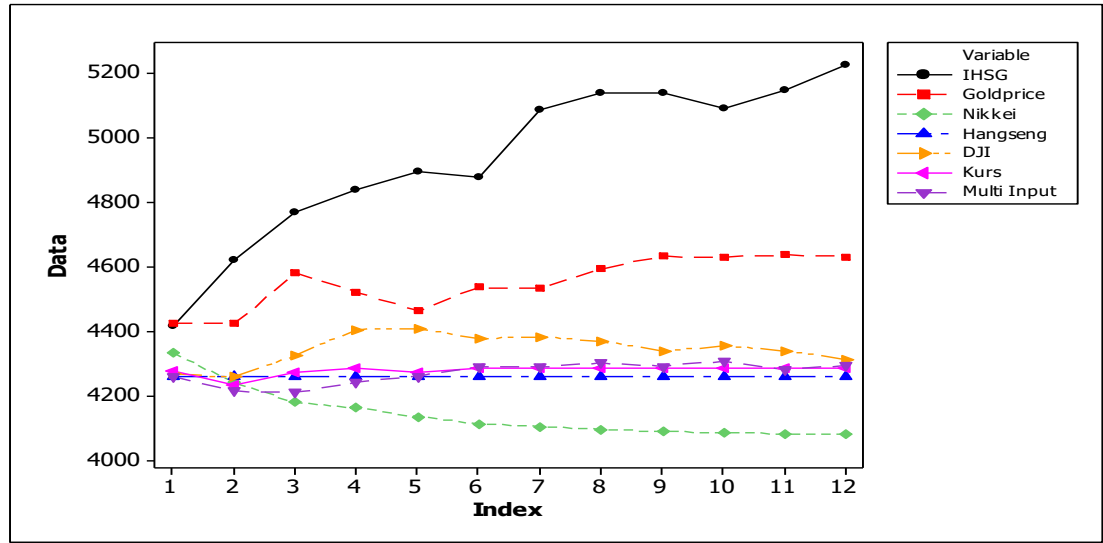

Gambar 10. Time Series Plot data IHSG hasil ramalan untuk keenam model fungsi transfer secara serentak 


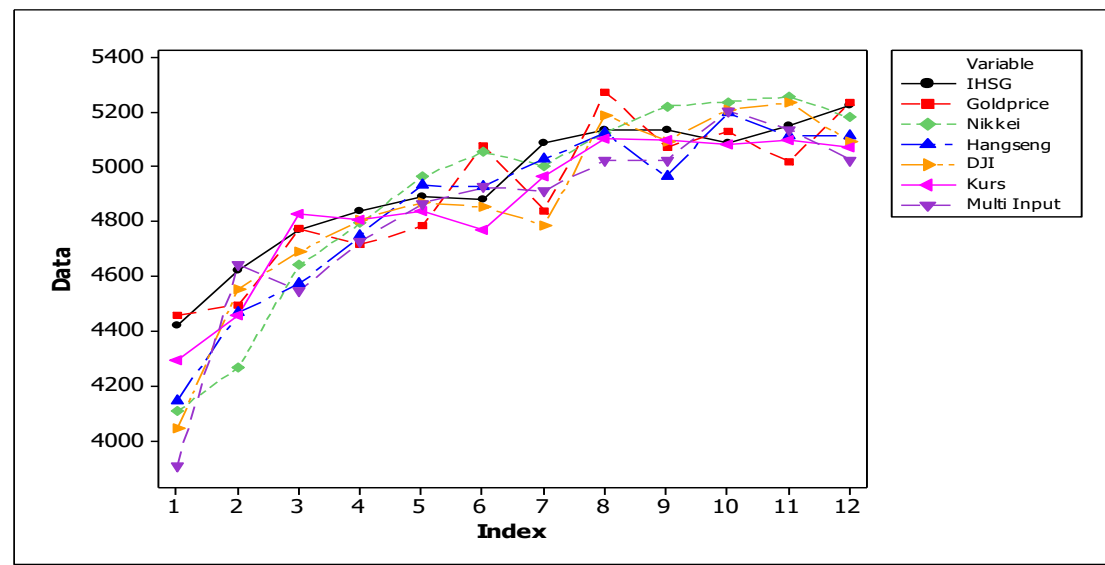

Gambar 11. Time Series Plot data IHSG hasil ramalan untuk keenam model fungsi transfer secara one step Forecasting a head

Dengan membandingkan hasil ramalan kedua cara di atas dapat dilihat bahwa ramalan dengan one step forecasting yaitu ramalan untuk 12 periode ke depan dengan meng-update data aktual periode sebelumnya merupakan cara yang terbaik untuk memperkirakan nilai IHSG periode yang akan datang karena lebih mendekati data aktual.

Tabel 1. Perbandingan nilai MAPE untuk keenam model fungsi transfer

\begin{tabular}{|c|l|l|l|}
\hline No & Model & $\begin{array}{l}\text { Nilai MAPE } \\
\text { untuk } \\
\text { ramalan } \\
\text { serentak }\end{array}$ & $\begin{array}{l}\text { Nilai MAPE } \\
\text { untuk } \\
\text { ramalan one step } \\
\text { forecasting }\end{array}$ \\
\hline 1 & $\begin{array}{l}\text { Input Harga emas } \\
\text { dunia }\end{array}$ & 0.0770 & 0.0208 \\
\hline 2 & $\begin{array}{l}\text { Input Indeks } \\
\text { Nikkei Indeks }\end{array}$ & 0.1583 & 0.0273 \\
\hline 3 & $\begin{array}{l}\text { Input Hangseng } \\
\text { Hat Indeks DJI }\end{array}$ & 0.1348 & 0.0226 \\
\hline 4 & Input Ino & 0.0230 \\
\hline 5 & Input Kurs & 0.1314 & $\mathbf{0 . 0 1 6 4}$ \\
\hline 6 & Multi Input & 0.1333 & 0.0290 \\
\hline
\end{tabular}

Setelah membandingkan nilai Mean Absolute Percentage Error (MAPE) dari keenam model fungsi transfer dapat diketahui dengan jelas bahwa model fungsi transfer dengan input Kurs melalui one step forecasting a head memberikan nilai ramalan yang mendekati dengan data aktualnya karena memiliki nilai MAPE yang paling kecil dibandingkan dengan kelima model lainnya.

\section{KESIMPULAN}

Berdasarkan hasil-hasil dan pembahasan pada bab sebelumnya dapat diambil kesimpulan sebagai berikut:

1. Berdasarkan perbandingan MAPE antara keenam model fungsi transfer untuk peramalan nilai IHSG diperoleh bahwa model peramalan yang paling baik untuk meramalkan nilai IHSG periode ke depan adalah model fungsi transfer one step forecasting dengan input Kurs karena memiliki nilai MAPE paling kecil, yaitu 1,64\%. 
2. Dari keenam model persamaan fungsi transfer baik dengan input tunggal maupun dengan multi input dapat diketahui bahwa kelima predictor yaitu harga emas dunia, indeks Nikkei, indeks Hangseng, Indeks DJI dan Kurs dollar terhadap rupiah berpengaruh siginifikan terhadap nilai IHSG.

\section{Daftar Pustaka}

Anoraga, Pandji, 2003. Pengantar Pasar Modal, edisi revisi, Rineka Cipta, Jakarta.

Edlund, P. E., 1984. "Identification of The Multi-Input Box Jenkins Transfer Function model", Journal Of Forecasting, vol. 3, 297-308.

Enders, Walter, 2004. Applied Econometric Time Series, 2nd ed., John Wiley \& Sons, Inc., USA.

Gujarati, D. N., 1995, Basic Econometrics, 3rd ed., McGraw Hill, New York.

Hanke, J. E., Wichern, D.W., dan Reitsch, A.G. 2001. Business Forecasting (seventh edition). New York : Prentice Hall International, Inc.

Makridakis, S., Wheelwright, S. C., dan McGee, V. E., 1983. Metode dan Aplikasi Peramalan, edisi 2, Bina Rupa Aksara.

Wei, W. W. S. 1990. Time Series Analysis, United States of America : Addison-Wesley, Inc. 